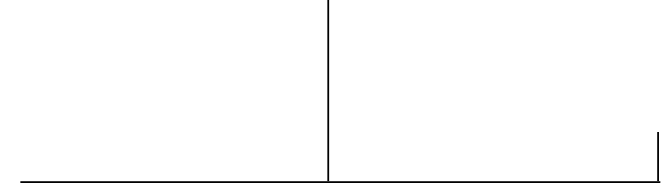

Rev. Latinoam. Psicopat. Fund., São Paulo, v. 11, n. 2, p. 329-335, junho 2008

\title{
Cartas de Hermelino Lopes Rodrigues e Juliano Moreira'
}

\section{$1^{\text {a }}$ Carta de Lopes Rodrigues para Juliano Moreira}

Professor Juliano Moreira.

Querido Mestre,

Nem sempre a razão estava com Sêneca: Victor jeroces impietus hebet... O "impulso" do vencedor, aqui, se transmuda em serenidade reverente ao demérito e à humildade.

1. Em 1959, Francisco de Sá Pires, discípulo de Hermelino Lopes Rodrigues publicou um pequeno livro com enfoque nas realizações de Lopes Rodrigues à frente da diretoria do Instituto Raul Soares, primeiro estabelecimento destinado ao tratamento dos insanos mentais em Belo Horizonte. O livro teve uma pequena circulação, e é muito raro encontrar um exemplar original. Além de fotos sobre a experiência realizada no Instituto Raul Soares, encontramos nele algumas cartas praticamente inéditas trocadas entre Lopes Rodrigues e Juliano Moreira. As cartas reproduzidas na publicação de Pires não têm datas. Essa correspondência é de grande relevância para estudiosos da História da Psiquiatria e enfoca especificamente aspectos históricos do ensino psiquiátrico no Brasil. As cartas aqui republicadas foram transcritas de Pires, Francisco de Sá. Lopes Rodrigues o louco: homenagem dos seus discípulos. Rio de Janeiro: IBGE, 1959. (Nota de Renato Diniz Silveira, que selecionou e transcreveu as cartas). 
Encontrando, em Minas, um meio de homens profundamente cultos, respirei, desde o primeiro momento, um ar de dignidade compatível com as aspirações do meu destino. Minas é uma terra de tradição, como convém a um temperamento afeito ao culto das tradições. Essa gente, daqui, reflexiva e cauta, terra de homens austeros, instruídos e veneráveis, só não quis ver o dilatado da minha escassez, para se demorar na bondade de transfigurá-la em méritos, fazendo-me professor.

Minhas apreensões, no meu primeiro concurso, para Docente-Livre aí, no Rio, foram maiores; talvez o fato de ter sido a primeira batalha da minha vida, senão a resistência silenciosa ao que o Mestre sempre me aconselhou contra os que se incomodam mais com o êxito alheio do que com os seus próprios insucessos. Como terá ecoado, aí, a notícia do meu concurso? Lamento o incômodo involuntário que mais este passo do meu destino estará a infligir aos que não se conformam com os passos do destino dos outros.

Quanto a mim, não tenho forças para me defrontar com o Mestre, sobraçando o título de professor, o que, se me desvanece como desfecho da minha maior aspiração, colide com a realidade da minha eterna condição de menor dos seus discípulos. Professores há muitos, neste mundo; discípulos de Juliano Moreira há poucos - e não é dado ser senão a muito poucos. Epicarmo dizia do seu discípulo: "Prevejo, se vejo claramente, que perdurarão no futuro as minhas lições ..." Sem me comparar, não pretenderei jamais as alturas do discípulo Platão, mas, muito aquém do neófito que se tornara o maior filósofo grego, continuo a ultrapassá-lo na veneração ao Mestre. Seis anos, ao seu lado, se não me mostraram, de todo, a justa medida da minha pequenez, bastaram para me ter mostrado a exata medida da sua grandeza. É o que me acode, como primeiro impulso da consciência, no átrio das primeiras homenagens do meu êxito, ao foco de luz em que ele se fascina e donde reverbera: meu sábio mestre...

Em breve, estaremos juntos e muito lhe terei a falar da grande impressão que me causou o saber dos mineiros, em cujo seio se casam autênticos humanistas a homens de grande compleição moral. É uma nobre cidade, de latinistas austeros, beletristas sóbrios e homens de serões prolongados, à sombra de camilianas, em meditados folheios.

Para quem, como eu, detesta as evidências públicas, os píncaros efêmeros e as glórias dos tumultos, esta cidade se afigura a cidade ideal dos retraimentos fecundos. Parece que farei dela a Hélade da completação do meu destino; reclinar, para sempre, na minha biblioteca, em confidência com as suas sempre amáveis prateleiras.

Continue a me ensinar e a me estimar, pois, face a face destas duas condições, os meus anseios, solícitos pela primeira, disputam a honra de me esforçar, para sempre merecer a segunda. 
Recomende-me muito aos sábios mestres e prezados amigos Henrique Roxo, Rocha Vaz e Ulisses Viana, aos quais envio, por intermédio, o meu abraço carinhoso.

Discípulo e amigo. Lopes Rodrigues.

(Hermelino Lopes Rodrigues, apud Pires, 1959, p. 15)

\section{Carta de Juliano Moreira para Lopes Rodrigues}

\section{Meu caro Poeta.}

Estão chegando por aqui algumas notícias sobre o seu ato revolucionário, soltando as feras do Instituto e recebendo, por isso, o batismo de louco. É que a sua reconhecida pacatez transformou, de uma hora para a outra, os hábitos de uma cidade. Vá, entretanto, com calma. Roma não se fez num dia. Nunca imaginamos que o senhor fosse encontrar as coisas que encontrou aí. Vá com prudência. Mesmo assim não se esqueça de que os doentes da mente merecem o mesmo trato dado às musas. Aceite o epíteto de louco em tão propícias condições ao seu renome no futuro. Aceite o epíteto de louco antes que lhe ponham outro pior. Todos nós devemos fazer a profilaxia da parcela de insulto que nos cabe. Agarre-se a esta e continue a soltar as "feras" com a mesma pachorra. Cada mineiro que o chamar de louco está passando um atestado triste na cultura de sua própria terra e de sua própria gente. Não creio aliás que todos os mineiros estejam de acordo; em todo caso a campanha de sua loucura já chegou até aqui. Marche para frente e não olhe para os lados.

Se mais não puder fazer em benefício dos seus doentes mentais, basta receber o batismo de louco por ter feito a libertação dos mesmos. Não se esqueça de ir documentando tudo que for fazendo. Lembre-se do ditado da nossa velha Bahia quando diz que o futuro a Deus pertence. Documente-se o quanto puder. Envie-me algumas fotografias.

Não digo que estude menos, mas com mais método, poupando as noites. Recomende-me ao Balena, ao Werneck e ao Borges da Costa. Augusta lhe manda lembranças.

Do sempre. Juliano Moreira.

(Juliano Moreira, apud Pires, 1959, p. 68) 


\title{
$2^{\text {a }}$ Carta de Lopes Rodrigues para Juliano Moreira
}

\author{
Professor Juliano Moreira.
}

Mestre e amigo.

Acabo de ler a sua carta, com o prazer de quem se deleita numa ambrosia dos numes de Salamina.

Achei muita graça em haver chegado até aí o título de doido com que acaba de ser agraciada a minha decisão, menos de enfrentar a posteridade, do que fruir, no sossego da consciência, o prêmio de ter enfrentado os homens de juízo e desalgemado os insanos e inconscientes.

Lembre-se do velho adágio: Insanus lapides, verbaque dura facit, isto é, "de doido, pedrada ou má palavra". Na impossibilidade de qualquer má palavra, o que a minha higiene verbal coíbe, estou no conceito desta gente, atirando pedras... Estou "doido varrido".

"Santo Agostinho já dizia que este mundo se ri de todos os que se não riem dele. Como, realmente, não acho do que me rir, divirto-me com o frouxo de riso, a gargalhada, o pânico desta bela cidade, a me conferir o título de louco, por ter 'soltado as feras"....

Não sei se o mestre se recorda de quando a Assembléia, por amor a Pisístrato, batizou Sólon de insensato, por ter começado a sua administração decretando a Lei Seisacteia, que dava liberdade dos bens a pessoas, ao que ele respondera: "Não estará longe o tempo em que meus concidadãos saberão qual a minha loucura". Ao libertar os loucos, não aspiro a glória, nem as ressonâncias presentes ou tardias. Dispus-me a transformar hienas manietadas, em seres humanos. Terei, ao menos, um Crítias que amenize a cicuta, quando, obrigado a ingeri-la, eu ordenar sejam pagas a Apolo as minhas dívidas históricas...

Minha luta não é contra a loucura, pois esta ainda tem, de quando em quando, os seus relâmpagos; minha luta é contra as obscuridades inacessíveis a um relâmpago.

Não se esqueça, Mestre, de que está bem perto de nós, a data - 1824 - na qual foi abolido o castigo corporal, tortura e ferro quente, contra os escravos; mesmo assim, para continuar a envergonhar, nesse passo, a Constituição do Império, ainda ficou o - açoite - , no Código Criminal. Imagine agora os pobres insanos!

Iniciei a minha tarefa de libertá-los, muito silenciosamente, como convém aos que sabem o que convém aos ditames da dignidade humana e como desejaria que ela terminasse. O senhor bem sabe o quanto detesto os ruídos da vanglória e os 
tumultos da exibição. Assim não o quis o "juízo" desta gente. A cada punho que eu desatava, reboava uma intempérie. Mau tempo, sim, mestre e amigo, qual frase de Sófocles, na boca do inefável Erasmo de Rotterdam: "Como é bom viver, mas sem sabedoria, porque esta é o veneno da vida". Estou documentando a tarefa, isto é, fotografando, arrolando e resguardando, em arquivos bem secretos, o instrumental de suplício dos doentes que encontrei em uso, no Instituto, pois sei que, ao rumor vozeante do presente, se seguirá o silêncio conjuratório, senão a negação contestante da posteridade. A ética e a aversão ao alarde me inibem de exibi-los em praça pública, onde se está erigindo, aqui, o monumento da minha "loucura". Que diria Fausto, quando interroga o nome de Mefistófeles e este responde, sobre aqueles que desprezam tanto as palavras, cheios de aversão por toda a aparência, não desejando senão penetrar na essência dos seres? Nur in der Wesen Tife trachet... é o que me acode à minha índole de retraído dos rumores de corredores e de ruas, continuando a achar que os maiores rumores, em torno da vida de um homem, não valem a glória de um minuto de silêncio, em torno da vida de toda a humanidade. Que hei de fazer, mestre amado? Eu trouxe, na minha via, este signo inevitável: evidenciado, sempre, pelo maligno tropel dos que me cercam, cada vez mais arraigado à religião do culto pelo silêncio do meu próprio tropel. No fundo de cada insulto glorioso deste batismo de "louco", ecoa o brado de um inconsciente, restituindo à luz do dia e das estrelas.

Do discípulo e amigo, Lopes Rodrigues.

(Hermelino Lopes Rodrigues, apud Pires, 1959, p. 81)

\section{$3^{\text {a }}$ Carta de Lopes Rodrigues para Juliano Moreira}

\section{Professor Juliano Moreira}

Mestre e amigo.

O ensino da Psiquiatria, na Faculdade, não me tem permitido passar dos monótonos expedientes de aulas teóricas, cujo cunho meramente tribunício se disfarça no aparato simulatório do seu mais sério imperativo: um paciente apanhado a esmo, entre os internados no Instituto, teatralizando a honestidade do ensino prático, na constrangedora e burlesca ação de presença a que o submetem tais colapsos da ética. O pobre paciente sentado a uma cadeira e eu, ao lado, fazendo uma preleção. É o que se denomina, aqui, em Psiquiatria, de aula... prática. 
Minha modesta, mas consciente formação psiquiatra, haurida aí, nas enfermarias do nosso velho hospital, acrisolada no trato clínico com o doente, vem rumorejando, pois, no verbalismo do espaldar de uma cátedra, sem serviços clínicos, sem doentes, sem que o seu professor, mesmo doutrinado dos ensinamentos das escolas germânicas possa conciliar as exigências mínimas de uma assistência com os imperativos mínimos do ensino. Em Munique, a Universidade se confunde com o asilo provincial, Kreis-Irren-Anstalt onde, já em 1861, mil quatrocentos e vinte e dois alunos faziam seus estudos, e assim Berlim, Breslau, Jena, Bonn, etc. Aqui, ainda se está em tais eras. Superei a primeira fase: a fase Pinel, a de humanização do Instituto, sua transformação em hospital, relegando a museu as relíquias medievais que encontrei. Pretendo, agora, subir a outra rampa do Calvário: uma reforma de assistência aos insanos, no Estado, cujas leis e regulamentos aqui se inspiram na cediça lei francesa de Ferrus, de 1830. Um hospital, ao nível de uma Universidade, no qual o ensino da Psiquiatria se processe de modo a que a Faculdade possa compensar as deficiências do seu professor nesta disciplina, com o que de mais severo se possa exigir na organização de um serviço didático, de modo a que eu não venha receber no porvir a coima de displicente para com o dever de organizar a minha cadeira na Faculdade, no momento em que tenho o ensejo de dirigir o hospital psiquiátrico do Estado. Mas estou cético. A primeira tarefa, que o mestre amado, generosamente, em sua última carta denomina de pineliana - dependia mais ou menos de mim próprio e a executei de um jato, conferindo-lhe estrategicamente o ímpeto de um imprevisto ciclone, no que consistiu a minha tática - não dar tempo a que os sábios da Grécia acordassem e a que a rotina se mobilizasse... A segunda tarefa, a da reforma regulamentar, depende de pôr "sábios", "bacharéis", "burocratas" e "morubixabas", dentro de artigos e parágrafos, enfrentar "trâmites legais", percorrer "canais competentes", defrontar "montanhas graníticas" e arrostar com influências, interesses e grupos. Acho muito difícil desburocratizar o Instituto e torna-lo na dignidade universitária do ensino, sob a autonomia do professor. Será o embate com feudos truculentos, matulas daltônicas e aglutinações perversas; todavia, o seu catedrático tem o dever de lutar até o fim, pela organização e pela dignidade do seu ensino e da sua cadeira. Se nada eu conseguir, fica a semente no chão. Meu olho clínico prognostica o êxito político destas duas figuras de estadista, que me apoiaram em minha primeira tarefa; Bias Fortes e Odilon Braga. Não sei porque os vejo, a ambos, no futuro, dirigindo os destinos de Minas. São realmente dois jovens políticos interessantes. E estou certo de que se não me for dado terminar minha tarefa, ou consolida-la, um deles, amanhã, no Palácio da Liberdade, não permitirá que as trevas da idade média recalcitrem no desapreço à dignidade do insano, em Minas Gerais. Só me desvanece, mestre amado, é estar dando curso ao im- 
perativo de uma consciência iluminada pela sua sombra. Continuo a encontrar menos luz nos raios de sol do que nas suas bênçãos espirituais. Nem o orgulho nem a exaltação tomarão de assalto a minha serena decisão de honrar a nossa velha oficina psiquiátrica da Praia Vermelha, onde mesmo à distancia ainda se vive sob a luz do seu egrégio candelabro.

Do discípulo e amigo, Lopes Rodrigues.

(Hermelino Lopes Rodrigues, apud Pires, 1959, p. 99)

\section{Juliano Moreira (1873-1933)}

Médico alienista baiano, um dos fundadores da disciplina psiquiátrica no Brasil, autor de vasta e original contribuição científica. Foi professor da Faculdade de Medicina da Bahia e diretor do Hospício Nacional de Alienados, no Rio de Janeiro, de 1903 a 1930.

\section{Hermelino Lopes Rodrigues (1898-1971)}

Vulto ímpar da Psiquiatria nacional, foi em sua época uma das mais profundas culturas médica e geral no Brasil. Discípulo de Juliano Moreira, foi médico do tradicional Hospital de Alienados da Praia Vermelha. 